\title{
VIOLÊNCIAS DE BAIXO, VIOLÊNCIAS DE CIMA NA REVOLUÇÃO RUSSA*
}

Nicolas Werth

A questão das violências de massa ocupa atualmente o centro da historiografia do século XX e admite-se que a Europa foi mesmo este continente sombrio magistralmente descrito por Mark Mazower. Devido à brutalização das sociedades pela Primeira Guerra Mundial, as Fúrias (Arno Mayer) grassaram, semeando As chamas do ódio (Norman Naimark).

Os conceitos de brutalização e de banalização das violências, propostos por George Mosse, revelam-se particularmente pertinentes para descrever a experiência vivida pela sociedade russa e, posteriormente, soviética, mergulhada entre 1914 e 1922 em uma "guerra prolongada de 8 anos" extraordinariamente violenta.

Essa brutalização da sociedade russa, sem igual nas sociedades ocidentais, foi o resultado de um processo cumulativo que associou vários fenômenos:

1) a brutalização belicosa, tanto mais forte porque, para a sociedade russa em revolução, o desfecho da Grande Guerra, ofi-

* Tradução de Thierry Calasans. Nossos agradecimentos à revisão de Ruy Fausto. 
cializado pelo tratado de paz de Brest-Litovsk em março de 1918, passa quase despercebido, já que os confrontos armados prosseguiram ao longo das frentes móveis de batalha de uma guerra civil já iniciada;

2) a reativação, de que falava Alexandre Herzen na metade do século XIX, da fratura profunda entre as "duas Rússias" - a Rússia "dominante" das cidades e a Rússia "dominada" do campo;

3) a exacerbação dos "antagonismos de classe";

4) o desmoronamento, momentâneo mas suficientemente duradouro para ser devastador, de todas as estruturas de enquadramento estatal e de autoridade. Ora, como se sabe, o risco de explosão de violência social é tanto mais forte quando o Estado está fraco;

5) a abolição, a partir de 1917, das fronteiras entre a esfera civil e a esfera militar, entre a guerra e a política, entre o "inimigo externo" e o "inimigo interno", entre as violências de guerra e as violências políticas.

Defensores de uma ideologia que fazia da violência das massas o motor da História, de um projeto político forte fundado no terror como instrumento primitivo, mas eficaz, de construção (ou, mais exatamente, de re-construção) do Estado, em uma verdadeira cultura política de guerra civil e em uma ideologia radical e explicativa que legitimava o uso da violência a serviço de um modelo político-militar de construção de uma sociedade nova, os bolcheviques souberam, melhor do que seus adversários, instrumentalizar e canalizar as violências sociais, restaurar a "gosoudarstvennost" (o "princípio do Estado") em face da "stikhia" (as forças desenfreadas e anárquicas da violência social).

Porém a brutalização do corpo social do ex-Império russo em guerra e em revolução teve em contrapartida um impacto crucial sobre o próprio bolchevismo. Ela fortaleceu um certo número de postulados leninistas sobre a violência como "verdade da política", ativou a identificação da polí- 
tica e da guerra, pois a política aplicada pelos novos atores sociais "que ingressaram no bolchevismo" a partir de 1917 transformou-se duradouramente, por meio de uma surpreendente inversão da fórmula de Clausewitz, em uma "continuação da guerra por outros meios".

Surgiu, assim, uma verdadeira "cultura política da violência" que se instalou, muito rapidamente, no coração do novo Estado "sucessor" do ex-Império czarista, a URSS. Nesta etapa de nossa introdução, ressaltemos imediatamente dois pontos importantes:

- Outros países beligerantes tiveram, até certo ponto, uma evolução idêntica, principalmente a Alemanha pós-1918 e a Itália, onde, com o surgimento do fascismo, a violência política tornou-se qualitativa e quantitativamente diferente do que havia sido no período anterior à guerra. A violência política bolchevique instalou-se, portanto, no centro de uma mudança verdadeiramente tectônica da cultura política européia, induzida pela Primeira Guerra Mundial.

- Na própria Rússia, as forças antibolcheviques implantaram, no clima geral de brutalização belicosa e de explosão das violências sociais, políticas de violência, cujas práticas (requisições, tomadas de reféns, execuções em massa, perseguições dirigidas de grupos inteiros classificados como "inimigos") lembravam fortemente aquelas aplicadas por seus adversários. Mas, apesar da similitude de algumas práticas, o "Terror Vermelho" e o "Terror Branco", que se desenvolveram inegavelmente no mesmo terreno, seriam da mesma natureza?

Para o historiador que se interessa pelo fenômeno das violências, o ex-Império russo dos anos 1917-1922, período que pode ser qualificado de "segundo tempo das perturbações" , foi um verdadeiro "laboratório experimen-

${ }^{1}$ Foi o general Denikin quem primeiro caracterizou assim, em suas memórias, 
tal", onde se expressaram as formas de violências sociais e políticas mais diversas e mais extremas, das mais "modernas" (deportações em massa de populações civis, bombardeios de vilarejos rebeldes com gases asfixiantes, campos de concentração) às mais "arcaicas" (reaparecimento em vasta escala do banditismo, insurreições camponesas, execuções imemoriais - tais como a empalação ou o enterro do inimigo ainda vivo). Essas violências multiformes, cujo estudo foi amplamente renovado pela historiografia mais recente, não devem certamente ser analisadas em função de uma única história política que culmina, ganha sentido e bascula em 25 de outubro de 1917.

Por tempo demais, cientistas políticos e historiadores concentraram-se apenas na violência bolchevique, decretada de cima, após outubro de 1917, e particularmente nos textos teóricos de Lenin, nos quais a questão da violência política constitui, como se sabe, um tema central. A análise 14 das violências que vêm de baixo, oriundas de uma sociedade em guerra, em revolução e em guerra civil foi longamente negligenciada, ainda que Marx tenha precisamente salientado que "as idéias não comportam violência em si mesmas. Para realizá-las, é preciso homens que exerçam a violência”.

Hoje em dia, principalmente graças a toda uma série de trabalhos recentes (cf. Acton, Cherniaev e Rosenberg, 1997) e à luz dos arquivos abertos desde a dissolução da URSS, é possível entender melhor a interação entre as violências sociais “de baixo” da Rússia em revolução e as violências políticas de cima, sobretudo a violência política bolchevique (mas não unicamente); entre a "brutalização" oriunda da Primeira Guerra Mundial e as "culturas políti-

Ocerki russkoi smuty (Paris, 1926), os anos 1917-1922. Essa caracterização foi retomada nos últimos anos por alguns historiadores desejosos de integrar as revoluções de 1917 ao "continuum de crises" iniciado em agosto de 1914 e encerrado, no que concerne à Rússia, somente em 1921-1922 (cf. Holquist, 2002). 
cas" (bolchevique e antibolchevique) implantadas a partir de 1917; entre a violência política "vermelha" e a violência política "branca".

\section{O impacto da Primeira Guerra Mundial}

Ao invés de reforçar a coesão - já muito fraca - de uma sociedade extremamente polarizada e "disjunta" ("out of joint", segundo a fórmula acertada de Leopold Haimson, 1964 e 1965), a guerra reativou a profunda fratura existente na Rússia entre as nizy (as "classes baixas") e as verki (as "classes superiores"), entre cidade e campo, citadinos e camponeses, consumidores e produtores, os combatentes e "os que se evadem".

Lembremos muito brevemente que o império russo já continha, antes da Primeira Guerra, um potencial muito grande de violência social. Podem-se distinguir ao menos três estratos, de desigual importância e intensidade:

- A violência urbana, reativa, do mundo operário em face da rigidez das relações capitalistas. Essa violência remetia ao traumatismo industrial de uma sociedade capitalista em plena expansão; ela já tinha sua lenda, seus "feitos de guerra", seus mártires: os milhares de proletários mortos durante a grande insurreição revolucionária de dezembro de 1905 em Moscou.

- A violência camponesa, aquela de um mundo rural servil até 1861, apenas duas gerações antes de 1917. Violência "asiática", temida não somente pelo poder czarista, mas também pela intelligentsia progressista, de Tchekov a Gorki, e da qual desconfiavam os próprios bolcheviques, Lenin em primeiro lugar. Essa violência secular despertou no início do século, em 1902, e depois, com mais força ainda, no decorrer dos eventos revolucionários de 1905-1906, marcados por formidáveis insurreições camponesas, esmagadas em sangue.

- O ressentimento mais difuso, mais surdo, mas presente, de alguns povos alóctones, na Ásia central, no Cáucaso, às margens 
ocidentais do Império, dos países bálticos à Ucrânia, "zona de residência" dos judeus do Império. Todas essas minorias são submetidas a discriminações, a violências maiores ou menores: deportações em massa dos "povos montanheses" do Cáucaso nos anos 1860, expedições punitivas de tipo colonial na Ásia central, progroms contra os judeus no início dos anos 1900 etc.

Com a guerra, reativam-se algumas dessas tensões profundas. A retaguarda sofre, desde o final de 1914, os efeitos dos desequilíbrios estruturais da economia russa. A guerra desnuda as falhas de uma modernização econômica inacabada. A economia russa não resiste por muito tempo à continuidade de um conflito prolongado, total, sem precedentes. O sistema de transportes logo fica desorganizado. A reconversão das fábricas para o esforço militar quebra o mercado interno. A indústria não tem mais condições de garantir as necessidades dos civis. Não podendo adquirir 16 produtos industriais, os camponeses diminuem em muito o abastecimento às cidades. Uma surda hostilidade ganha os citadinos, cada vez mais esfomeados, contra os habitantes rurais. Nas cidades, a penúria e a inflação radicalizam os conflitos, que atingem seu nível mais baixo no início da guerra, entre operários e patrões.

No front, a debacle de 1915, atribuída tanto à escassez dramática de armamentos, de material e de munições, quanto à incompetência, senão à traição de alguns oficiais de alto nível introduzidos nos meios da Corte, reaviva surdas tensões. Em um exército onde o soldado-camponês (cerca de $90 \%$ dos recrutas) é tratado mais como um servo do que como um cidadão, um número crescente de soldados vê em seus oficiais superiores os representantes detestados dos verkhi, que não somente lhes impunham regras degradantes de disciplina, mas os haviam levado para os "abatedouros mundiais" da guerra imperialista. Em março de 1917, um oficial escreve: 
"Quando nós (os oficiais, $N W$ ) falamos do povo (narod), consideramos a nação como um todo, mas eles, quando falam dele, referem-se apenas às massas populares democráticas (demokraticeskie nizy). Seja qual for sua atitude pessoal em relação a um oficial ou outro, aos olhos deles não passamos de senhores (bary)" ${ }^{2}$.

Apesar dessas tensões, as deserções e os atos de indisciplina no exército permaneceram fatos excepcionais até o verão de 1917. O cansaço dos combatentes, os ressentimentos dos soldados só degeneraram em violências ativas quando as instituições de autoridade puseram-se a vacilar sob o efeito da propagação revolucionária, principalmente pelo viés decisivo dos comitês de soldados criados a partir de março de 1917.

Embora a guerra tenha trazido à tona fraturas sociais latentes, ela também inaugurou certas práticas de "gestão das populações" de uma extrema violência, até então experimentadas apenas nos "espaços coloniais" do Império russo (Ásia central, Cáucaso). A extensão desmedida da esfera militar, bem além da linha de frente, criou vastas zonas de não-direito submetidas à lei marcial, onde os chefes de exército puseram em prática algumas teorias, desenvolvidas desde o início do século nos meios militares, sobre as "populações suspeitas" em tempos de guerra (autóctones muçulmanos, judeus e súditos russos de origem alemã em particular). Assim, de setembro de 1914 ao final de 1916, mais de um milhão de cidadãos do Império russo, de origem judaica ou alemã, foram brutalmente expulsos e deportados por ordem das autoridades militares apenas em razão de sua origem étnica. Todos esses deportados, em teoria concentrados administrativamente em um certo número de pro-

\footnotetext{
${ }^{2}$ Cf. Revoljutsionnoie dvizhenie v armii i na flote. Sbornik dokumentov. Avgust 1914-fevral 1917, 1967, pp. 221-222.
} 
víncias distantes do teatro das operações militares, engrossaram a vaga dos milhões de refugiados que fugiam do avanço das tropas inimigas, mas também da política da "terra arrasada" aplicada pelo exército russo em retirada, principalmente na frente sudoeste. O êxodo de milhões de pessoas teve um efeito profundamente desestabilizador sobre a vida política, econômica e social da Rússia em guerra, sobre a extensão das violências. As migrações descontroladas e os deslocamentos forçados perturbaram as hierarquias sociais e as ordens cristalizadas da sociedade czarista. Nesse sentido, refugiados e transferidos contribuíram amplamente para fazer da Rússia em guerra uma "sociedade de areias movediças", já "em processo de revolução" bem antes de fevereiro de 1917. Essa prática de deslocamentos forçados de populações seria amplamente aplicada, ao longo dos anos seguintes, principalmente pelo novo regime bolchevique (cf. Gattrell, 1999; Hagen, 1998, pp. 34-57).

\section{0 ano de 1917}

Um fato maior surpreendeu os contemporâneos naquele ano: a explosão desordenada da violência cotidiana, por translação, por propagação da violência das zonas militares para a retaguarda, enquanto desmoronavam as instituições de enquadramento e de autoridade e se dissolvia o próprio Estado. Essa evolução deu-se progressivamente, ao longo de todo o ano, acelerando-se muito a partir do final do verão de 1917, marcado pela convergência momentânea de uma imensa insurreição, ponto culminante de um ciclo de revoltas camponesas começado no início do século, e da desagregação do exército russo. Foi precisamente essa convergência que criou uma dinâmica revolucionária inédita, da qual os bolcheviques souberam habilmente tirar partido.

Porém, antes de examinar esse ponto, gostaria de evocar a importante contribuição de toda uma série de estudos recentes, desenvolvidos tanto por historiadores russos, 
como Boris Kolonitskii (2001), quanto por ocidentais, como Orlando Figes (1996), sobre a evolução das representações coletivas durante o ano de 1917. Um dado impõe-se: a escalada de uma nova figura de "inimigo", não mais o inimigo externo, o "alemão", mas o inimigo interno, o rico, o burguês, o explorador. Segundo Boris Kolonitskii, é em abril de 1917 que surgem, nas resoluções de bairro dos sovietes de Petrogrado, Moscou e outras cidades, então amplamente dominados pelos socialistas-revolucionários, as primeiras menções à expressão "inimigos do povo", cuja importância conhecemos, após outubro, na argumentação e na estruturação do terror bolchevique.

Essa retórica do inimigo é alimentada por toda uma literatura socialista, mas não especificamente bolchevique. Entre as obras mais populares, os best-sellers de 1917, distribuídos em milhões de exemplares pelo conjunto das imprensas bolchevique, menchevique, socialista-revolucionária e anarquista, figuram panfletos de título sugestivo: As aranhas e as moscas (note-se que a imagem da aranha-burguês-vampiro sugando o sangue das moscas-trabalhadores resgata uma imagem bastante presente desde os anos 1900 na literatura anti-semita de extrema-direita, a aranha-vampiro representando o "capitalista-judeu"); ou então Por que não há mercadorias no campo e pão na cidade? Nesta última brochura, os temas populares do apoderamento, da especulação e da sabotagem, intensificados pelas dificuldades crescentes do abastecimento (realidade maior e constante do ano de 1917 nas cidades) são articulados em termos de luta de classes. Pode-se ler aí, notadamente:

“Os responsáveis pela penúria e pela fome são os senhores capitalistas, os donos de fábricas, os banqueiros, os burgueses [...]. Tudo é intencionalmente organizado para que a mão descarnada da miséria e da fome estrangule o povo trabalhador" (Iaroslavskii, 1917). 
Essa metáfora tornar-se-ia uma das mais célebres da Revolução, uma das mais exploradas pela propaganda bolchevique."Todos nossos problemas sociais e alimentares desembocam numa única solução" escreve com perspicácia o filósofo Nikolaï Berdiaiev em setembro de 1917,

"caçar o burguês, fonte de todos os males. Há alguns meses, o Inimigo era Nikkolacha [Nicolau II, NW], Alexandra [a Imperatriz, NW] e Grichka, o depravado [Rasputin, NW], que tramavam com o alemão. Hoje, o inimigo interno é o 'burguês'. Nas filas, 'burguês' tornou-se sinônimo de 'especulador' ou de 'judeu'. Para as massas sem trabalho, esfomeadas, cansadas da guerra, o 'burguês' é indistintamente todo indivíduo mais ou menos corretamente vestido, o intelectual, o comerciante, o estudante, o judeu, o que se evade" (Berdiaiev, 1991, p. 78).

Através das resoluções dos sovietes, dos comitês de bairros, dos comitês de fábrica, vê-se avançar, ao longo do ano de 1917, o que Máximo Gorki caracterizou justamente de "guerra plebéia contra os privilégios", reais ou imaginados. Solicita-se a requisição dos "apartamentos dos burgueses", onde seriam alojados "em nome da justiça” os "trabalhadores explorados", uma medida que será tomada pelos bolcheviques no início de 1918; exige-se (soviete de bairro de Vyborg, de maioria bolchevique, mas com uma forte minoria de socialistas-revolucionários) "que todos os proprietários que alugam mais de quatro quartos dirijam-se ao soviete para receber uma intimação para limpar as ruas e as latrinas públicas”. Essa discriminação, essa exclusão eram certamente apenas uma primeira etapa. Limito-me a citar duas petições, dentre inúmeras do mesmo tipo, enviadas ao soviete de Petrogrado em outubro de 1917. Seus signatários esclarecem suas simpatias políticas: "socialistas sem partido" e explicam como pode 
enfim realizar-se na Terra a aspiração secular do povo russo à "justiça" e à "liberdade":

"Os 20 milhões de burgueses em liberdade mantiveram na escravidão, durante séculos, os outros 160 milhões de nossa sociedade. A liberdade, hoje, deve existir para esses 160 milhões, os outros 20 milhões devem se submeter [...]. A liberdade só deve existir para os oprimidos. Para os opressores, o cacete. Somente com o cacete teremos justiça”.

Ou ainda:

"Nossa proposta: enviar todos os nobres e proprietários de terras, burgueses e membros da Okrana às Solovki ${ }^{3}$ [...]. É mais do que hora de reunir em um lugar seguro todos esses vermes para que deixem de envenenar com seus bolores pútridos a Rússia operária e camponesa" (Livsin e Orlov, 1998, pp. 250-269).

No outono de 1917, o slogan inscrito, alguns meses mais tarde, nas celas da Cheka - "Morte à burguesia!" - já estava em muitas mentes... No mesmo momento, as violências oriundas da decomposição do exército russo e do bunt (a revolta camponesa) convergiram em uma onda formidável. Para o dirigente menchevique Iuri Martov, a escalada do bolchevismo popular da segunda metade de 1917 foi precisamente a expressão política da cultura de guerra dos camponeses-soldados. Diante da vaga selvagem dos "capotes cinza", a tradição da social-democracia russa fora varrida, desfeita. A vitória do bolchevismo deu-se ao preço de uma ruptura sociológica com suas raízes operárias. Em contraste com a vulgata bolchevique (segundo a qual o bolchevismo seria a

${ }^{3}$ Ilhas do Mar Branco, local do primeiro grande campo de concentração da Rússia soviética (N.T.). 
expressão do movimento revolucionário da classe operária), a interpretação de Martov lembra o que o general Brussilov dizia do "bolchevismo de trincheiras", uma forma particular, transitória e efêmera de bolchevismo, evidentemente muito diferente do bolchevismo patente do pequeno grupo de militantes revolucionários profissionais conduzido por Lenin (essas duas formas iriam rapidamente entrar em conflito já em 1918). O "bolchevismo de trincheiras", que emergiu na segunda metade de 1917, fundava-se em três exigências maiores: a terra, a liberdade, a paz. Ele refletia a dupla natureza do soldado-camponês russo: um combatente esgotado por três anos de uma guerra terrível e um agricultor desejoso de ver enfim realizar-se o sonho secular simbolizado por duas palavras mágicas, Zemlia e Volia (a Terra e a Liberdade). A terra, pela "partilha negra"4, ou seja, a distribuição de todas as grandes propriedades e a redistribuição, sob a égide da comunidade camponesa, das terras "àqueles que as 22 laboram". A liberdade, isto é, a rejeição de qualquer imposição estatal, de qualquer instituição que não aquela oriunda da própria comunidade camponesa. A essas exigências maiores, que há muito faziam parte do programa defendido pelos socialistas-revolucionários, principais rivais políticos dos social-democratas, os soldados-camponeses acrescentavam uma terceira - a paz imediata, reivindicação defendida exclusivamente pelos bolcheviques (Werth, 2002a)

Reflexo das tensões profundas que minavam o exército czarista após três anos de guerra, o "bolchevismo de trincheiras" difundiu-se progressivamente graças a uma politização crescente do exército e de uma impaciência cada vez

\footnotetext{
${ }^{4}$ Em francês, partage noir, tradução do russo tchernyi peredel. Essa expressão significava, para os camponeses, a divisão de todas as terras pelos próprios camponeses em função das "bocas a serem alimentadas" (número dos membros da família, com um coeficiente bastante complexo: um adulto do sexo masculino = 1 parte; um adulto do sexo feminino $=0,8$ parte; um jovem de 16 anos, capaz de trabalhar $=0,7$ parte; uma criança $=0,3$ parte etc.) (N.T.).
} 
maior dos combatentes em dar um fim à guerra. Os comitês de soldados desempenharam um papel decisivo nesse processo. Em contato direto com a vida política da retaguarda, as casernas e as guarnições radicalizaram-se bem antes das unidades da linha de frente.

O fracasso da ofensiva de 18 de junho, a "contra-revolução militar” posta em ação em julho-agosto de 1917 (limitação das competências dos comitês de soldados, proibição de qualquer propaganda bolchevique, restabelecimento da pena de morte no front) e, mais ainda, o putsch abortado do generalíssimo Kornilov (final de agosto de 1917) constituíram, como mostrou Allan Wildman em seu estudo magistral sobre o exército russo em 1917 (Wildman, 1980), as três etapas maiores na radicalização e na bolchevização da tropa. A "traição" do generalíssimo precipitou as violências contra os oficiais e a decomposição do exército como força combatente e, mais ainda, como instrumento de repressão a serviço do Estado.

Em setembro-outubro de 1917 , cerca de um milhão de soldados-camponeses desertou de sua unidade e voltou para casa, entregando-se no caminho aos mais diversos atos de violência: pilhagens de comércios, roubos à mão armada, estupros coletivos, saques de pequenas cidades, pogroms, destruição das casas de proprietários de terras e execução dos ocupantes que não tinham tido tempo de fugir. A violência das zonas militares propagou-se da zona do front para a retaguarda à medida que se desagregava o exército como instituição, que desmoronavam as instituições de enquadramento e de autoridade, que se dissolvia o próprio Estado. A brutalização gerada por três anos de guerra convergiu então com a violência do bunt, e desertores e permissionários deram um impulso decisivo ao movimento camponês. A partir do final de agosto, as agitações agrárias, até então relativamente limitadas e moderadas, transformaram-se, principalmente nas regiões onde a 
fome de terras era mais gritante, mas também nas regiões próximas do front, em verdadeiras insurreições. Embora os habitantes dos vilarejos participassem em massa da pilhagem dos domínios, os instigadores eram, na maioria das vezes, os soldados, geralmente armados, que tinham voltado para casa. Além das destruições dos "ninhos de nobres" e da execução de seus ocupantes, uma das formas mais espetaculares de exações cometidas pelos desertores, que se deslocavam em bandos formados às vezes por milhares de indivíduos, era a pilhagem de pequenas cidades. Essas violências tinham freqüentemente uma coloração antisemita (pogroms das cidades bielo-russas de Bobruisk, Nesvij, Gomel). Na realidade, eles prolongavam, de maneira "espontânea" e anárquica, as práticas muito brutais de deportação da população judaica aplicadas, de maneira sistemática e “ordenada”, pelo exército russo em 19151916. Por toda parte, a proliferação maciça de desertores, 24 de permissionários, de militares "autodesmobilizados", com freqüência sem o menor pecúlio e sem possibilidade de voltar para casa, traduziu-se por uma escalada espetacular das violências - ataques à mão armada, roubos, saques, rixas, estupros - nas cidades onde a ordem pública não era mais assegurada ${ }^{5}$ :

"A barbárie camponesa de capote cinza invadiu as cidades, [escreve em outubro de 1917 Máximo Gorki]. Ela está presente em todo lugar, ela escorre e cheira mal. A revolução não passa de um pogrom de ódio, de vinganças e de frustrações, uma explosão de instintos zoológicos, uma revolta russa de onde a psicologia socialista está ausente, mas onde desponta o asiatismo".

\footnotetext{
${ }^{5}$ Cf. Revoljutsionnoie dvizhenie v Rossii v 1917 g (O movimento revolucionário na Rússia em 1917), Moskva, 1957, 6 vol, em particular o volume 6, que cobre os meses de setembro-outubro de 1917.
} 
Foi graças a esse clima de violências e de caos, de deliqüescência de toda autoridade estatal, civil e militar, que os bolcheviques tomaram o poder.

Nessa etapa, os bolcheviques são os únicos a encorajar, a instrumentalizar essa violência devastadora. Desde os primeiros meses da guerra, no final de 1914, Lenin definira assim:

"a essência do trabalho bolchevique: visar à transformação da guerra imperialista em uma guerra de classes, em uma guerra civil” (Lenin, 1962, pp.13-14).

Para Lenin, de fato, a violência da luta das classes é o motor da História, o revelador das relações de força, a "verdade da política”, a "ordália materialista”. Deve-se encorajar essa violência "purificadora" a fazer sua obra de destruição do "velho mundo" (lembremos o que Lenin dissera sobre as insurreições camponesas de 1905-1906:

"Os camponeses não destruíram senão um décimo quinto dos domínios, um décimo quinto somente do que deveriam ter destruído para livrar definitivamente a terra russa dessa ignomínia que é a grande propriedade rural”.

Encorajar a violência das massas, mas também:

“organizá-la, controlá-la, subordiná-la aos interesses e às necessidades do movimento operário e da luta revolucionária geral, da ditadura revolucionária do proletariado [definida como] um poder conquistado e mantido pela violência, que o proletariado exerce sobre a burguesia, poder que não está ligado a nenhuma lei”.

“Organização”, “controle”, “depuração”, são as palavraschave de um texto fundamental de Lenin de dezembro de 
1917, "Como organizar a emulação?”, no qual ele chama as "massas conscientes" a orientar a violência para um

“objetivo único: purificar a terra russa de todos os insetos nocivos, das pulgas (os vigaristas) e dos percevejos (os ricos)".

A animalização do Inimigo (que, como se viu, não é nem nova nem apanágio dos bolcheviques) só pode evidentemente encorajar a violência.

Enquanto instrumentalizam a violência social "de baixo", os bolcheviques, assim que tomam o poder, desenvolvem uma "cultura política da violência", uma "cultura de guerra civil”, marcada por uma rejeição a qualquer acordo, qualquer desvio de obstáculo, qualquer negociação, qualquer divisão do poder. Dentre as medidas mais importantes figuram: a oficialização, desde o final de novembro de 1917, 26 da noção "de inimigo do povo" (termo surgido, como já vimos, alguns meses antes); a criação, no início de dezembro de 1917, de uma polícia política, a Cheka, órgão multifuncional (policial, político, extrajudiciário e econômico) com poderes inicialmente limitados, mas que vão aumentar rapidamente de maneira exponencial; a generalização da prática da tomada de reféns "pertencentes às classes ricas"; a dispersão violenta (com uso de armas) de qualquer manifestação antibolchevique, inclusive aquelas oriundas dos meios operários; a implantação de um sistema de campos de concentração onde o internamento, por simples medida administrativa, não tinha outra justificativa senão "o pertencimento a uma classe hostil”. Essas práticas variadas inspiram-se, poderíamos dizer, no "espírito da época”, uma época marcada pela escalada do que Marc Ferro denominou "absolutismo popular", pela onipresença da figura do Inimigo, pela translação do inimigo externo combatido desde 1914 para o inimigo interno - uma translação ilustrada 
de maneira exemplar pelos primeiros campos de concentração. Com efeito, muitos deles foram instalados no lugar dos campos de internamento dos prisioneiros de guerra alemães e austro-húngaros, progressivamente libertados, na primavera de 1918, em aplicação ao tratado de paz de BrestLitovsk. Nesse momento - primavera de 1918 - uma outra etapa começa, a da guerra civil, mas também a da construção, pelos bolcheviques, de um novo Estado.

\section{Anos 1918-1922: as guerras civis no ex-Império russo}

Os anos 1918-1922 foram, por muito tempo, analisados sob um único aspecto: o de um enfrentamento militar e ideológico entre forças revolucionárias (os "Vermelhos") e contra-revolucionárias (os "Brancos"). Na realidade, esses anos de guerra civil, marcados por conflitos multiformes (Vermelhos contra Brancos, mas também Verdes - camponeses desertores que fugiam do alistamento militar e se opunham às requisições - contra os "Vermelhos" e os "Brancos", ucranianos contra judeus, citadinos contra camponeses, povos "colonizados" da Ásia central contra os "colonizadores" russos), foram, antes de tudo, um momento de fortíssimas tensões entres as forças sociais - em particular o campesinato - ou nacionais centrífugas que desejavam prosseguir sua revolução iniciada em 1917, uma revolução antiestatal, anticentralizadora, de forte conteúdo libertário e localista, e forças políticas ("Vermelhos", mas também "Brancos") que tentavam restabelecer, nas zonas que controlavam, o Estado que se desagregara no decorrer de 1917, tornar a impor o controle das cidades sobre o campo, mobilizar homens e recursos indispensáveis para combater o adversário.

Nessa empreitada, os bolcheviques tiveram mais sucesso que seus oponentes, por uma série de razões que recapitulei rapidamente na minha introdução. Na verdade, os "Brancos" não tinham outro projeto senão uma volta ilusória a um passado mistificado e que não oferecia nenhuma perspectiva de 
renovação ou de integração social. Quanto aos socialistas-revolucionários, cujas idéias foram, por um determinado período, compartilhadas pela maioria, eles permaneceram profundamente presos a uma concepção estritamente localista e descentralizada do poder, que os privava de perspectivas concretas de organização e de construção de um Estado.

Voltando à questão das violências, um primeiro ponto que deve ser ressaltado é o fato de que todas as forças políticas em luta deflagraram contra os seus inimigos métodos que já haviam sido empregados contra o inimigo externo durante a Primeira Guerra Mundial, particularmente, as instituições e as práticas de uma mobilização total, a política sendo pensada como a continuação da guerra. Um segundo ponto: a importância da luta contra os "inimigos internos" na retaguarda das linhas de combate, muito instáveis, que se opunham aos exércitos regulares. Essa luta freqüentemente degenerou em 28 uma "guerra suja de pacificação", cujas vítimas principais foram os civis: camponeses refratários que recusavam a mobilização e o alistamento, perseguidos pelos dois lados; "simpatizantes" bolcheviques e judeus massacrados pelos Brancos e pelos vários exércitos ucranianos; membros do clero e das elites do antigo regime tomados como reféns e massacrados pelos Vermelhos.

Retomemos mais detalhadamente o processo, particularmente violento, de "reimposição do Estado" pelos bolcheviques, um processo iniciado cerca de seis meses após outubro de 1917, e saudado, à época, por vários de seus adversários, tais como os liberais Maklakov ou Miliukov.

Lenin, como também muitos especialistas e tecnocratas não-bolcheviques, era fascinado pelo modelo de capitalismo do Estado alemão desenvolvido durante a guerra:

"Nós precisamos [escreve em maio de 1918] aprender com o capitalismo de Estado alemão, assimilá-lo com todas as 
nossas forças, não hesitar diante dos métodos ditatoriais para acelerar, ainda mais do que fizera Pedro I, a assimilação do ocidentalismo pela Rússia bárbara, não hesitar em utilizar métodos bárbaros para lutar contra a barbárie" (Lenin, 1962, p. 101, grifos do autor).

A "barbárie" aqui mencionada é, antes de tudo, a "barbárie" camponesa, o "asiatismo" das massas rurais, amaldiçoado por Lenin enquanto intelectual russo, por um lado, e marxista, por outro, para quem fora o campesinato conservador que selara o destino da Comuna de Paris - referência fundamental, particularmente durante a instalação do novo regime bolchevique.

A "batalha pelos cereais" - que acobertava uma luta contra os "koulaks" - introduzida pelos dirigentes bolcheviques em maio de 1918, ao conferirem plenos poderes ao Comissariado do Povo para o Abastecimento, verdadeiro Estado dentro do Estado, representa, é claro, uma resposta específica a uma situação de crise nas trocas entre cidades e meio rural (bem anterior à tomada do poder pelos bolcheviques), que se traduz, no início da primavera de 1918, por imensas dificuldades de abastecimento nas cidades, bastiões do novo poder. Mas essa "batalha pelos cereais" não é somente econômica. Os bolcheviques estão decididos, através da "ditadura do abastecimento", a impor novamente o "princípio do Estado" aos "pequenos proprietários que têm horror à organização e à disciplina”. Por três anos consecutivos, destacamentos do "exército do abastecimento" (cerca de 300.000 homens em 1920) do todo-poderoso Comissariado do Povo para o Abastecimento, vão manter um clima de extraordinária violência nos campos. Temos aqui também um notável exemplo de instrumentalização, pelos bolcheviques, das tensões entre as cidades e o meio rural - essas milícias armadas, em sua maioria compostas por desempregados ou elementos do lúmpen-proletariado, esfomeados 
e dispostos a tudo para se apropriar, pela força, do trigo "retido pelos koulaks". As exações dessas milícias armadas foram a origem da maioria dos motins e revoltas camponesas que eclodiram em 1919, culminando em 1920-1921 (Tchapannaia voina nas províncias de Samara e de Simbirsk na primavera de 1919, guerras camponesas na Ucrânia em 1919, insurreições camponesas de Tambov - Antonovschina, em 1920-1921, da Sibéria ocidental em 1920-1921). Essas guerras camponesas, que mesclavam elementos "modernos" (a maioria dos chefes dos exércitos camponeses eram oficiais que tinham se formado durante a Primeira Guerra) e elementos muito "arcaicos", constituíram uma das particularidades mais fortes - e até recentemente subestimadas - das guerras civis russas, e ao mesmo tempo uma experiência formadora e decisiva no decorrer da qual se forjavam numerosas práticas de violência do novo regime.

Esse processo de "reimposição do Estado", que o his30 toriador Mikhail Frenkin caracterizou justamente como a primeira grande operação "contra-revolucionária” desenvolvida com sucesso no meio rural russo desde o esmagamento, pelo estado czarista, das insurreições populares de 1906-1907, desenvolveu-se num clima de extraordinária violência e de arbitrariedade absoluta, fato confirmado por documentos da Cheka sobre a situação no meio rural, recentemente publicados sob a direção do Prof. Danilov (Danilov e Berelowitch, 1998). Nessa espiral de violências, mesclavam-se brutalidades "arcaicas” às quais, há séculos, as autoridades tinham recorrido para domar servos e camponeses revoltados (tais como a bastonada ou a flagelação pública), e violências "modernas" destinadas a aniquilar "o inimigo interno", segundo métodos testados nas frentes da Grande Guerra: desocupação dos vilarejos de seus habitantes, deportados ou transferidos para campos de concentração; fuzilamentos em massa de reféns. Freqüentemente comandados por oficiais formados nas escolas militares cza- 
ristas e aliados do regime bolchevique a partir do momento em que este demonstrou a sua resolução em esmagar as revoltas campesinas, os destacamentos punitivos (chamados, de maneira significativa, "destacamentos de extermínio" - istrebitel'nye otriady) empregaram técnicas de guerra testadas nos campos de batalha da Grande Guerra: bombardeio de vilarejos pela artilharia, fuzilamento em massa de reféns, uso de gás de combate para "limpar" as florestas nas quais se escondiam os "bandidos"

Essas violências não eram, evidentemente, apanágio de nenhuma das partes. Os camponeses insurgidos, agrupados em bandos armados compostos de milhares de homens, entregaram-se a práticas de uma violência extrema e ostentatória, destinadas a aterrorizar o adversário. Assistiu-se a um incrível ressurgimento do fenômeno do "banditismo social", sinal tangível, dentre vários outros, da formidável regressão que o país enfrentou entre 1918 e 1922. Um primeiro tipo de banditismo, que correspondia ao modelo imutável da "rebelião primitiva" evidenciada por Eric Hobsbawm, pode ser salientado. Tratava-se de bandos de "vingadores" (mstiteli) que operavam localmente. Esses bandos atacavam prioritariamente os funcionários do poder soviético, saqueavam os prédios públicos, símbolos do poder "estrangeiro" na cidade, destruíam os documentos fiscais, cortavam as linhas de estradas de ferro, saqueavam os silos do Estado onde eram estocados os cereais requisitados, chegando a redistribuir aos camponeses os grãos retomados. Eles eram compostos, essencialmente, por desertores, por refratários ao alistamento militar e por outros camponeses que se tornaram foras-da-lei por terem se oposto às requisições, fugido do alistamento pelo Exército Vermelho ou desafiado o representante local do poder; não eram, naturalmente, isentos de elementos criminosos. Nas províncias

\footnotetext{
${ }^{6}$ Sobre essas violências, cf., em particular, Danilov e Shanin (1994).
} 
da Rússia central, na Ucrânia (e, naturalmente, na Ásia e no Cáucaso, onde o banditismo "costumeiro" era uma forma tradicional de resistência contra a russificação), a maioria dos bandos evoluía em um perímetro conhecido, beneficiando-se geralmente do apoio da população local. Nas regiões pouco povoadas - estepes do Don e do AlémVolga, florestas dos Urais e da Sibéria - operava um outro tipo de bandos - os bandos ditos "voadores", muito mais heterogêneos, compostos por marginais, criminosos, desertores, proscritos (particularmente antigos oficiais do Exército Branco) e desenraizados em busca de um lar ou de um destino, ambos improváveis, deixados anos antes. Soberbamente descritos por Boris Pasternak (Doutor Jivago), esses bandos, compostos por vezes de centenas de cavaleiros e de soldados de infantaria, deslocavam-se com armas (pesadas) e bagagens (carroças) por grandes distâncias podendo atingir mil quilômetros (Werth, 2002b).

32 Tanto quanto uma rejeição radical do novo regime, a experiência guerreira adquirida nas frentes da Grande Guerra e a brutalização que se seguiu, unificava, nessas formações paramilitares, percursos e destinos individuais muito diferentes. Os bandos mais estruturados e que opuseram a mais longa resistência eram, em geral, aqueles provenientes de motins de unidades do Exército vermelho. Dominando as técnicas militares, comandados por oficiais experientes, eles apresentavam certo número de traços comuns. Os seus chefes eram, na maioria, camponeses mobilizados durante a Grande Guerra. "Introduzidos na política” nos comitês de soldados do exército em 1917, tinham aderido ao partido socialista revolucionário ou bolchevique antes de serem promovidos a oficiais no Exército Vermelho. Após terem combatido contra os Brancos, eles haviam rompido - uma vez afastada a ameaça de uma restauração do Antigo Regime - com o que consideravam uma "traição aos ideais revolucionários" pelos "falsos bolcheviques". 
Os destacamentos de camponeses dirigidos pelo comandante amotinado do Exército Vermelho Andreï Sapojkov foram batizados, de forma significativa, de "Primeiro Exército da Verdade". Em seu manifesto (13 de julho de 1920) o "Soviete militar revolucionário do Primeiro Exército da Verdade" afirmava que "na Rússia soviética, o poder dos camponeses trabalhadores tinha há muito tempo desaparecido". Todas as instituições "ditas soviéticas" eram, na realidade, dirigidas por "inimigos da revolução - proprietários fundiários, burgueses e oficiais". Nesses "tempos de perturbações", o tema da impostura do poder - um tema mobilizador de todas as grandes revoltas campesinas que sacudiram o império russo por séculos - ressurgiu com força. Apresentando-se como "vingadores", como os "autênticos defensores dos camponeses oprimidos", os "bandidos" se entregavam a exações de uma violência extrema e ostentatória contra os representantes do poder dos "falsos comunistas": os funcionários que caíam em suas mãos eram condenados à morte de forma atroz, num arrebatamento de violência demonstrativa destinada a aterrorizar o adversário - congelados vivos no inverno, após serem aspergidos por água, empalados ou enterrados até o pescoço e assim deixados como alimento aos animais. Não esqueçamos a dimensão anti-semita dessa violência: na Bielorússia e na Ucrânia ocidental, os bandos conduzidos por Balakhovitch, Golak, Orel-Galitchevski, Vassili Popov e outros chefes de bandos que permanecem no anonimato, perpetraram, com o apoio dos camponeses locais, numerosos pogroms, cujas vítimas se contam às dezenas de milhares. O seu alvo principal era, de forma significativa, a "comuna judaica" (zidovska kommuna), já que os bolcheviques (que tinham tentado criar, na rica Ucrânia, kolkhozes ou sovkhozes) estavam amalgamados aos judeus, que, para o camponês ucraniano, eram esses "estrangeiros" cujo modo de vida, religião e costumes eram tão profundamente diferentes. Nesses afrontamentos, um 
grande mito estava nascendo, cujas conseqüências seriam tão dramáticas para toda a história do século XX europeu o mito do "judaísmo-bolchevismo" (Miliakova, 2006).

Os Brancos, bem como as unidades nacionalistas ucranianas de Simon Petliura, requisitaram também sem distinção, recrutaram à força, cometeram numerosos massacres de civis desde que houvesse desconfiança de que pertenciam a uma "categoria suspeita": "bolcheviques" ou "judeus". As violências mais terríveis das forças antibolcheviques foram direcionadas contra a população judia, particularmente na Ucrânia e na Bielorússia, vítima dos maiores massacres (pelo menos 150.000 mortos) perpetrados contra essa comunidade antes do Holocausto. Os dirigentes militares Brancos sempre atribuíram esses massacres aos "excessos incontroláveis", negando qualquer ação premeditada e qualquer plano de conjunto. No entanto, a amplitude e o caráter sistemático dos massacres dos judeus levaram ao questionamento da existência, 34 mais ou menos admitida, mais ou menos consciente, de uma intenção "eliminadora", remetendo a um anti-semitismo radical, muito presente há anos em alguns oficiais do alto escalão do exército czarista. Desde 1914, estes haviam tido, mais de uma vez, a oportunidade de proceder a deportações maciças de populações judias, e até mesmo de participar de um dos vários pogroms que tinham acompanhado a decomposição do exército czarista em 1917.

No entanto, pode-se dizer globalmente que a violência bolchevique foi mais abertamente assumida, reivindicada, mais teorizada do que a violência antibolchevique. Foi também mais desinibida, pois mais "abstrata", fundada em uma sorte de cientismo, o conhecimento das leis da História e da evolução das classes sociais, sendo que algumas, como a burguesia, deveriam necessariamente desaparecer: os responsáveis pela Cheka, por exemplo, explicavam que não matavam indivíduos, mas exterminavam, por meio deles, uma classe social condenada pela História: 
"Nós exterminamos a burguesia como classe [afirmava Latsis, um dos adjuntos de Dzerjinskii]. Nós não procuramos estabelecer a culpa de tal ou qual indivíduo perante o poder soviético. A primeira questão que nos colocamos é a de seu pertencimento a uma classe, de suas origens sociais, de sua educação, de sua profissão. Esses parâmetros definem o destino do indivíduo incriminado. Tal é a essência do Terror Vermelho" (Krasnyi Terror, 1918, p. 1).

Essa concepção era amplamente compartilhada pelos simples executores. Questionado sobre o fato de não ter ao menos promovido um processo verbal mínimo das condenações à morte e das execuções, um chekista de base proferiu esta extraordinária réplica:

"Para que todas essas formalidades administrativas se estamos liquidando os koulaks e os burgueses como classe?”.

Este "terror de classe" era permanentemente justificado pelo fato de um mundo novo estar nascendo. Tudo era permitido, como explicava o editorial do primeiro número de Krasnyi Metch ( $O$ Gládio Vermelho), jornal da Cheka de Kiev:

"Rejeitamos os velhos sistemas de moralidade e de 'humanidade' inventados pela burguesia com o intuito de oprimir e de explorar as classes inferiores. Nossa moralidade não tem precedentes, nossa humanidade é absoluta pois ela repousa sobre um novo ideal: destruir toda forma de opressão e de violência. Para nós, tudo é permitido pois somos os primeiros no mundo a levantar a espada, não para oprimir e reduzir à escravidão, mas para libertar a humanidade de suas correntes. Sangue? Que o sangue jorra! Pois somente o sangue pode colorir para sempre a bandeira negra da burguesia pirata, em estandarte vermelho, bandeira da Revolução!” (Krasnyi Metch, 1919, p. 1). 
Última particularidade deste "Terror Vermelho" - foi no mais alto nível do Partido que ele foi decretado, ao menos no tocante a alguns de seus episódios mais sangrentos (mesmo se, na prática, os responsáveis locais conservavam uma importante margem de iniciativa): o famoso "Decreto sobre o Terror Vermelho" do dia 5 de setembro de 1918, ponto de partida dos primeiros grandes massacres em massa (10 mil a 15 mil execuções sumárias em dois meses); ou ainda a diretiva secreta do dia 24 de janeiro de 1919 sobre a "descossaquização", chamando-a

"um terror maciço contra os cossacos ricos que deverão ser exterminados e fisicamente eliminados até o último e, em geral, contra todos os cossacos que participaram direta ou indiretamente da luta contra o poder soviético" (Werth, 2004).

Como resultado dessa diretiva, cerca de 10 mil a 12 mil 36 homens foram executados em algumas semanas, depois de um julgamento sumário por um tribunal militar revolucionário. Esta desmesura de terror, erigida a política sistemática, só parou quando o Exército Vermelho foi obrigado a recuar em face da rebelião cossaca. Ela foi retomada dezoito meses mais tarde sob outra forma: a deportação total, dada como exemplo, de toda a população (cerca de 50 mil pessoas) de meia dúzia de grandes burgos cossacos da região do Terek, particularmente rebeldes ao poder soviético. Notemos, no entanto, que essas deportações punitivas permaneceram, se considerarmos a escala do país e tendo em vista as violências extremas da guerra civil, limitadas. Em 1920, a logística era notadamente deficiente para levar a cabo as operações de deportação de maior envergadura: falta de comboios ferroviários, de carroças, de cavalos, desorganização por conta da insegurança geral num ambiente não pacificado. A “descossaquização” permaneceu um grande projeto inacabado. 
Atingimos, aqui, um dos limites deste terrível nó de violências: o esgotamento material, físico e moral dos combatentes - e, de forma geral, do próprio país, exangue, desindustrializado (lembremos que em 1921 a produção industrial havia caído para 12\% do nível de 1913!), desurbanizado. Mais do que uma vitória militar sobre os camponeses insurgidos, foi a grande fome de 1921-1922 (nas regiões do Volga, mas também nas estepes do Don) que pôs fim às guerras camponesas.

A trégua com o campesinato, decretada pelos dirigentes bolcheviques no X Congresso do Partido (março de 1921), quando as requisições foram finalmente substituídas pelo imposto em mercadorias, a NEP (Nova Política Econômica) foi adotada e o "Comunismo de Guerra" abandonado, desorientou profundamente todo o aparato político-militar bolchevique que tinha se formado nas guerras civis e para o qual não havia outro horizonte político senão a guerra contra os inimigos internos. Desde 1922, um responsável de cúpula da OGPU relatava a Felix Dzerjinski:

"Nossos chekistas têm saudade dos anos nos quais extorquir, saquear, cobrar uma contribuição extraordinária da burguesia era o pão de cada dia. Eles vivem o seu estatuto de pequeno funcionário como sendo uma profunda decadência [...] No período atual, assistimos a uma degenerescência progressiva de nossos homens. Se nada for feito, o Estado correrá o risco de se deparar com um aparelho que não funciona"

Notável confissão, que toca o cerne do funcionamento do sistema: a necessidade permanente de reativar a dinâmica da violência que, do ponto de vista dos bolcheviques,

7 RGASPI (Arquivos de Estado da Rússia em História Social e Política), 76/2/306/224. 
tinha dado resultados extraordinários no decorrer dos anos 1917-1922. Essa dinâmica da violência está no centro da dinâmica totalitária, uma dinâmica fundada na identificação da política e da guerra ou, mais especificamente, como escreveu Pierre Hassner:

"na inversão da fórmula clausewitziana por uma formulação comum a Lenin e a Ludendorf, de acordo com a qual 'a política é a continuação da guerra por outros meios'” (Hassner, 1999, p. 368).

A trégua é, a curto prazo, a "degenerescência”. Degenerescência dos ativistas, afogados no "oceano rural", degenerescência do Partido, infiltrado por "elementos socialmente estranhos", degenerescência do Estado, infiltrado por "especialistas burgueses".

Relançar a dinâmica revolucionária, pôr fim, preventi38 vamente, a processos sociais e políticos que correm o risco de escapar a todo controle - tal foi o sentido da grande ofensiva de transformação brutal e acelerada lançada pelo grupo stalinista no final dos anos 1920. Para essa segunda revolução, essa "Revolução de cima" (Robert Tucker), a experiência fundadora dos anos 1918-1922 foi ao mesmo tempo um modelo para a ação e uma etapa "heróica" a ser ultrapassada.

\section{Nicolas Werth}

é diretor de pesquisa do Institut d'Histoire du Temps Présent, no Centre National de la Recherche Scientifique (CNRS-IHTP). 


\section{Bibliografia}

ACTON, E.; CHERNIAEV, V.; ROSENBERG W. (eds). 1997. Critical companion to the Russian Revolution, 1914-1921. London: Arnold.

BERDIAIEV, N. 1991. Socinenija [Obras]. Moskva: Nauka.

DANILOV, V. P.; BERELOWITCH A. (eds.). 1998. Sovetskaia derevnia glazami VCK, OGPU, NKVD [O meio rural soviético visto pela Cheka, OGPU, NKVD]. Moskva, Rosspen, vol. 1, 1918-1922.

DANILOV, V. P.; SHANIN, T. (eds.). 1994 Antonovschina. Krestianskoie vosstanie v Tamovskoi gubernii, 1920-1921 [A Antonovschina. A insurreição campesina na província de Tambov, 1920-1921] Tambov.

FIGES, O. 1996. A people's tragedy. The Russian Revolution, 1891-1924. London: Jonathan Cape.

GATTRELL, P. 1999. A whole empire walking. Refugees in Russia during World War I. Bloomington, IN: Indiana University Press.

HAGEN, M. Von. 1998. "The Great War and the mobilization of ethnicity”. In: BARNETT, R.; SNYDER, J. (eds.). Post-Soviet political order: conflict and state-building. London: Routledge, pp. 34-57.

HAIMSON, L. 1964. "The problem of social stability in urban Russia, 1905-1917”. Slavic Review, vol. 23/4, pp. 619-642.

HAIMSON, L. 1965. "The problem of social stability in urban Russia, 1905-1917”. Slavic Review, vol. 24/1, pp. 1-22.

HASSNER, P. 1999. "Par-delà l'histoire et la mémoire" [Além da história e da memória]. In: ROUSSO, H. (dir.). Stalinisme et nazisme. Histoire et mémoire comparées [Stanilismo e nazismo. História e memória comparadas]. Bruxelas-Paris: Complexe, IHTP, p. 368.

HOLQUIST, P. 2002. Making war, forging revolution. Harvard U.P.: Cambridge.

IAROSLAVSKII, E. 1917. Otcego net tovarov v derevne, xleba v gorodax? [Por que não há mercadorias no campo e pão na cidade?]. Moskva.

KOLONITSKII, B. 2001. Simvoly vlasti $i$ bor'ba za vlast' [Os símbolos do poder e a luta pelo poder]. Sankt Peterburg: Iz. DB.

KRASNYI Metch. [ O gládio vermelho]. 1919. n 1, Kiev, 18 de agosto.

KRASNYI Terror [O terror vermelho]. 1918. $\mathrm{n}^{\circ} 1$, Kazan, $1^{\circ}$ de novembro.

LENIN, V. I. 1962. Polnoie sobranie socinenii [Obras completas]. Moskva, vol. 29.

LIVSIN, A.; ORLOV, I. 1998. "Revoljutsia i spravedlivost. Posleoktiabrskie pis'ma vo vlast" [Revolução e equidade. As cartas do poder após outubro de 1917]. In: TIUTIUKIN, S. (ed.). Oktiabrskaia revoljutsia. Ot novyx istocnikov $k$ novomu osmysleniju [A Revolução de Outubro. Das novas fontes a uma nova interpretação]. Moskva, pp. 250-269. 
MAYER, A, 2000. The furies: violence and terror in the French and Russian Revolucion. Princeton: Princeton University Press.

MILIAKOVA, L. B. (ed.). 2006. Kniga pogromov [O livro dos pogroms]. Moskva: Rosspen.

NAIMARK, N. 2001. Fires of hatred: ethnic cleasing in the twentieth-century Europe. Cambridge, Mass.: Harvard University Press.

Revoljutsionnole dvizhenie v armii $i$ na flote. Sbornik dokumentov. Avgust 1914-fevral' 1917 [O Movimento revolucionário no exército e a frota. Coletânea de documentos. Agosto 1914 - Fevereiro 1917]. Moskva.

RevolJutsionnoIE dvizhenie v Rossii v $1917 \mathrm{~g}$ [O movimento revolucionário na Rússia em 1917]. 1957. Moskva, 6 volumes.

RGASPI [Arquivos de Estado da Rússia em História Social e Política].

WERTH, N. 2002a. "Les déserteurs en Russie: violence de guerre, violence révolutionnaire et violence paysanne (1916-1921)" [Os desertores na Rússia: violência de guerra, violência revolucionária e violência campesina (1916-1921)]. In: AUDOIN-ROUZEAU S. et al. (dir.). La violence de guerre, 1914-1945. Bruxelles: Complexe, pp. 99-117. 2002b. "Les rebelles primitifs en URSS" [Os rebeldes primitivos na URSS]. Communisme, ${ }^{\circ}$ 71-72, pp. 57-87. 2004. "Les déportations de 'populations suspectes' dans les espaces russes et soviétiques, 1914 - fin des années 1940: violences de guerre, ingéniérie sociale, excision ethno-historique" [As deportações de "populações suspeitas" nos espaços russos e soviéticos, 1914 - final dos anos 1940: violências de guerra, engenharia social, excisão etnohistórica]. Communisme, $\mathrm{n}^{\circ}$ 78-79 (2-3), pp. 19-20.

WILDMAN, A. 1980. The end of the Russian Imperial Army. Princeton: U.P., vol. 1. 


\section{D)}

\section{VIOLÊNCIAS DE BAIXO, VIOLÊNCIAS DE CIMA NA REVOLUÇÃO RUSSA}

NICOLAS WERTH

Defensores de uma ideologia que fazia da violência das massas o motor da História, de um projeto político fundado no terror como instrumento primitivo e em uma visão radical e explicativa que legitimava o uso da violência a serviço de um modelo político-militar de construção de uma sociedade nova, os bolcheviques souberam, melhor do que seus adversários, instrumentalizar e canalizar as violências sociais. Porém, a brutalização do corpo social do ex-império russo teve, em contrapartida, um impacto crucial sobre o próprio bolchevismo. Ela fortaleceu certos postulados leninistas sobre a violência como "verdade da política" e ativou a identificação da política e da guerra por meio de uma surpreendente inversão da fórmula de Clausewitz, "a política como continuação da guerra por outros meios”. Surgiu, assim, uma verdadeira "cultura política da violência" que se instalou, muito rapidamente, no coração do Estado "sucessor" do ex-império czarista, a URSS.

Palavras-chave: Revolução Russa; Violência social e violência política; Bolchevismo; União Soviética.

\section{VIOLENCES FROM BELOW, VIOLENCES FROM ABOVE IN THE RUSSIAN REVOLUTION}

Supporters of an ideology which made mass violence the engine of History, and a political project founded on Terror as a primitive tool and a radical view which endorsed violence at the service of a political-military model to a new society, the bolsheviks were able, as no one else, to use and channel social violences. However, the brutalization of the social body of the old Russian empire had a 
crucial effect on Bolshevism itself. It enhanced some Leninist assumptions on violence as "the truth of politics" and activated the identification of politics and war, surprisingly inverting Clausewitz's words, "politics as the continuation of war through other means". In the end, a true "political culture of violence" emerged within the very heart of the State which replaced the Tzarist Empire, the USSR.

Keywords: The Russian Revolution; Social and political violence; Bolshevism; The Soviet Union. 